\title{
Molecular Modeling and in Silico Characterization of a Pathogenesis-Related Protein-10 (PR10) and its Coding Genes in some Oryza Species
}

\author{
Ahmed Sayed Fouad* \\ Rehab Mahmoud Hafez \\ Received 30/6/2019, Accepted 15/9/2019, Published 18/12/2019 \\ This work is licensed under a Creative Commons Attribution 4.0 International License.
}

\begin{abstract}
:
Rice is a major staple food for more than two thirds of the world population. Pathogenesis-related proteins-10 (PR10) have a range of 154 to 163 amino acid with molecular weight $\sim 17 \mathrm{kDa}$. They are acidic and generally intracellular and cytosolic proteins accumulate in plants in response to biotic and abiotic stresses. In the present study, a PR10 gene and its corresponding protein were characterized in $O$. sativa, $O$. barthii, $O$. glaberrima, O. glumipatula, O. meridionalis, $O$. nivara, $O$. rufipogon and $O$. punctata. The results revealed a narrow range of variation at both DNA and protein levels in all examined species except $O$. glumipatula. The latter showed a relatively obvious structural variation at protein level. Such variation may be beneficial against different types of stress that requires further elucidation to exploit in rice breeding programs.
\end{abstract}

Key words: Genomes, Rice, Wild relatives.

\section{Introduction:}

Rice is the second most important cultivated world cereal crop occupying 167 million hectare yielding 770 million ton a year (1). It is a major staple food for about two thirds of the world population having a balanced carbohydrates, proteins and lipids content $(2,3)$. There is a growing demand for rice production in addition to biotic as well as abiotic stresses necessitate production of novel cultivars having better qualitative and quantitative agronomic performance (4).

Only two Oryza species (O. glaberrima and $O$. sativa) are cultivated but unhappily having a narrow range of genetic diversity that do not exceed $20 \%$ of that observed in wild Oryza species (5, 6). Attempts are going to characterize DNA sequence diversification in wild Oryza species uncovering a broad range of intera- and interspecific variations (7-9) that afford a natural pool for genetic information fundamental for breeding programs (10).

Starting with $O$. sativa (ssp. japonica cv. Nipponbare) genome (389 Mb) sequenced in 2004 (11), efforts aided with next generation sequencing (NGS) technologies have established full sequence of several wild Oryza species genomes.

Botany and Microbiology Department, Faculty of Science, Cairo University, 12613 Cairo, Egypt.

"Correspondence: ahmedsfouad@yahoo.com
The resulted DNA sequences are now freely available in several data bases creating an ore from which precious genetic information can be easily mined. The in silico analyses have several advantages over wet lab-based tools of being time saving and cost effective. It can be completed based on free open-sources and software (12) that fasten recognition and characterization of potentially important genes essential for genetic improvement of the present cultivated rice cultivars.

The in silico analyses were recruited to identify several important genes in Oryza species including genes encoding enzymes controlling shikimate pathway (13), salt stress responsive genes (14), regulatory elements for pathogenesis-related proteins (15), nucleotide binding site-leucine-rich repeats playing an important role in the plant defense (16) and Cyclin dependent kinase B (CDKB) gene (17).

As a general defense response, plants accumulate a group of proteins known as pathogenesis related (PR) proteins (18). Based on biological activities, serological relationships and primary structure, PR proteins are classified into 17 families (19). PR10 proteins are a huge group of PR proteins sharing common features of being small (154-163 amino acid; molecular mass $17 \mathrm{kDa}$ ), acidic and generally intracellular and cytosolic (19, 20). Amino acids sequence analysis reflected glycine-rich loop (p-loop) having the sequence GXGGXG in most PR10 protein; it can be 
considered as a signature motif for PR10 proteins (20). Such sequence is presumed to act as a binding site for nucleotides essential for RNase activity recorded for some PR-10 proteins $(19,20)$.

PR10 proteins spread all over the plant kingdom suggesting indispensable functions (21). The first publications concerning such proteins referring to the results of exposure of parsley cell suspensions to a fungal elicitor $(22,23)$. Thereafter, members of PR10 class were found to accumulate in response to infections with viruses (24), bacteria (25) and fungi $(26,27)$ as well as abiotic stresses (28-30).

The full-length cDNA of a PR10 gene was cloned from roots of $O$. sativa Japonica group by Hashimoto et al. (31). It was demonstrated to encode a 160 amino acid protein (16.9 kDa, pI 4.74). Interestingly, the gene was found to be upregulated in response to drought, salinity and infection with rice blast fungus bearing potential capabilities against both biotic and abiotic stresses. Therefore, the aim of this study is to characterize this PR10 protein and their coding genes in other cultivated rice and some wild related Oryza species employing in silico analysis.

\section{Materials and Methods:}

The amino acid sequence of a PR10 protein (BAD03969.1) in Oryza sativa (Japonica Group) downloaded from NCBI (http://www.ncbi.nlm.nih.gov) was targeted in genomes of $O$. sativa Indica Group, $O$. barthii, $O$. glaberrima, O. glumipatula, O. meridionalis, $O$. nivara, $O$. rufipogon and $O$. punctata in EnsemblPlants database (http://www. http://plants.ensembl.org) employing BLASTP search tool to distinguish the candidate genes, coding sequences, amino acids sequences as well as location on chromosomes.

Genomic and coding sequences of the retrieved genes were employed to construct exon-intron structure using Gene Structure Display Server website (http://gsds.cbi.pku.edu.cn/). In conjunction with the PR10 genes in the closest monocot grasses (Hordeum vulgare, Sorghum bicolor and Triticum aestivum) available in Gene Bank, the sequences mined from Oryza species were aligned using
Clustal W. Aligned sequences were utilized to create a phylogenetic tree based on Maximum Likelihood (ML) method in MEGA v. 6 (32) following Kimura 2-parameter model (33) with gamma distribution. Significance of support for grouping pattern was assessed depending on Bootstrap of 1000 replicate (34).

Retrieved amino acid sequences of the selected Oryza species were aligned with aid of multiple sequence alignment (multalin) (35, http://multalin.toulouse.inra.fr/multalin) to determine characteristic motif and consensus domains. Physico-chemical features of the predicted proteins including molecular mass and isoelectric points were determined using Expasy Protparm server http://us.expasy.org/tools/protparam.html).

Subcellular localizations of the retrieved proteins were predicted using the CELLO2GO server (37). 3-D model and secondary structure for the predicted proteins were constructed with aid of the Phyre2 server (38, http://www.sbg.bio. ic.ac.uk/phyre2). Z-score for the predicted 3-D models was calculated using ProSA-web server (39, https://prosa.services.came.sbg.ac.at/prosa.php).

\section{Results and Discussion:}

Results of the present investigation reflected occurrence of the predicted PR10 gene on chromosome 12 in all studied Oryza species. Genes share an open reading frame (ORF) ranged from $474 \mathrm{bp}$ (in $O$. glumaepatula) to $480 \mathrm{bp}$ (in the remaining species) in two exons spaced with 294603 bp intron (Table 1 and Fig. 1). Similar results were recorded in $O$. sativa by 15 . Kaur et al. (15); the authors recorded an OFR of $483 \mathrm{bp}$ arranged in 2 exons flanking an 297 bp intron. The same features were observed in $O$. sativa by Ozyigit et al. (40). Generally, the same exon-intron structure is a characteristic feature for PR10 genes. It was recorded in several plant species including Vitis vinifera (41), Panax ginseng (42), Zea Mays (27), Sorghum bicolor, Medicago truncatula, Prunus persica, Glycine max and Solanum tuberosum (40), and Arabidopsis thaliana (15). 
Table 1. Chromosome distribution and position of exons and introns of a PR10 gene in some Oryza species

\begin{tabular}{|c|c|c|c|c|c|c|c|c|c|c|}
\hline \multirow[b]{2}{*}{ Species } & \multirow{2}{*}{$\begin{array}{c}\text { Chromo } \\
\text { some }\end{array}$} & \multicolumn{3}{|c|}{ Exon 1} & \multicolumn{3}{|c|}{ Intron } & \multicolumn{3}{|c|}{ Exon 2} \\
\hline & & Start & End & $\begin{array}{c}\text { Length } \\
\text { (bp) }\end{array}$ & Start & End & $\begin{array}{c}\text { Length } \\
\text { (bp) }\end{array}$ & Start & End & $\begin{array}{c}\text { Length } \\
\text { (bp) }\end{array}$ \\
\hline O. sativa Indica gp & 12 & 301 & 475 & 175 & 476 & 771 & 296 & 772 & 1076 & 305 \\
\hline O. sativa Japonica gp & 12 & 301 & 475 & 175 & 476 & 772 & 297 & 773 & 1077 & 305 \\
\hline O. barthii & 12 & 301 & 475 & 175 & 476 & 798 & 323 & 799 & 1103 & 305 \\
\hline O. glaberrima & 12 & 301 & 475 & 175 & 476 & 798 & 323 & 799 & 1103 & 305 \\
\hline O. glumipatula & 12 & 301 & 475 & 175 & 476 & 769 & 294 & 770 & 1068 & 299 \\
\hline O. longistaminata & 12 & 301 & 475 & 175 & 476 & 770 & 295 & 771 & 1075 & 305 \\
\hline O. meridionalis & 12 & 301 & 475 & 175 & 476 & 1078 & 603 & 1079 & 1383 & 305 \\
\hline O. nivara & 12 & 301 & 475 & 175 & 476 & 771 & 296 & 772 & 1076 & 305 \\
\hline O. punctate & 12 & 301 & 475 & 175 & 476 & 1057 & 582 & 1058 & 1362 & 305 \\
\hline O. rufipogon & 12 & 301 & 475 & 175 & 476 & 771 & 296 & 772 & 1076 & 305 \\
\hline
\end{tabular}

Species

Exon - Intron Structure

O. sativa Indica gp
O. sativa Japonica gp
O. barthii
O. glaberrima
O. glumipatula
O. longistaminata
O. meridionalis
O. nivara
O. punctata
O. rufipogon

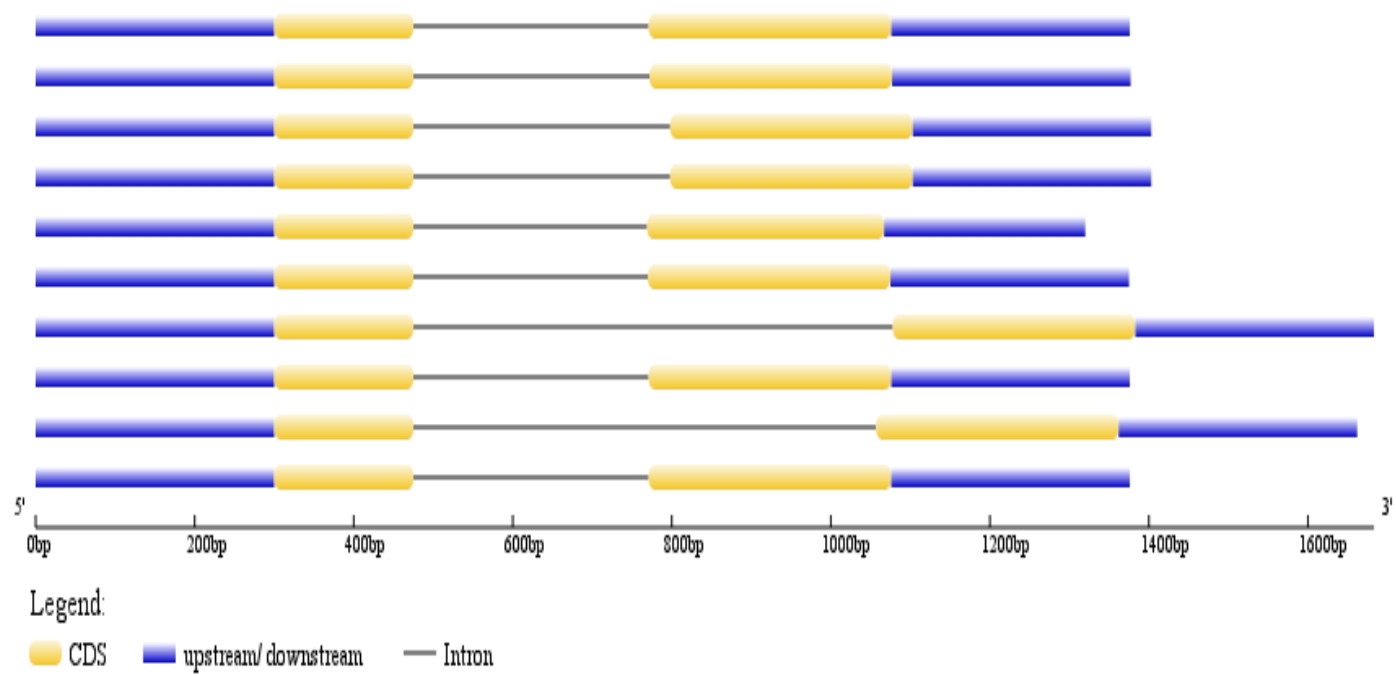

Figure 1. Exon-intron distribution of a PR10 gene in some Oryza species.

Phylogenetic analysis revealed grouping of all studied Oryza species in a major clade strongly supported with $100 \%$ bootstrap value (Fig. 2). Regarding relationships between the domesticated Oryza species (O. sativa and $O$. glaberrima) and wild ones, the phylogenetic tree showed that $O$. rufipogon and $O$. nivara are the closest wild taxa to $O$. sativa while $O$. barthii is the closest one to $O$. glaberrima. On the other hand, O. punctata appeared as an outgroup for other studied Oryza species. Similar phylogenetic relations were observed between wild and cultivated rices using trnL-trnF and ITS (43), whole chloroplast sequences (44), supermatrix of 4643 nuclear genes (45), centromeres and centromere-linked genes (46) and CDKB1 coding gene (17).

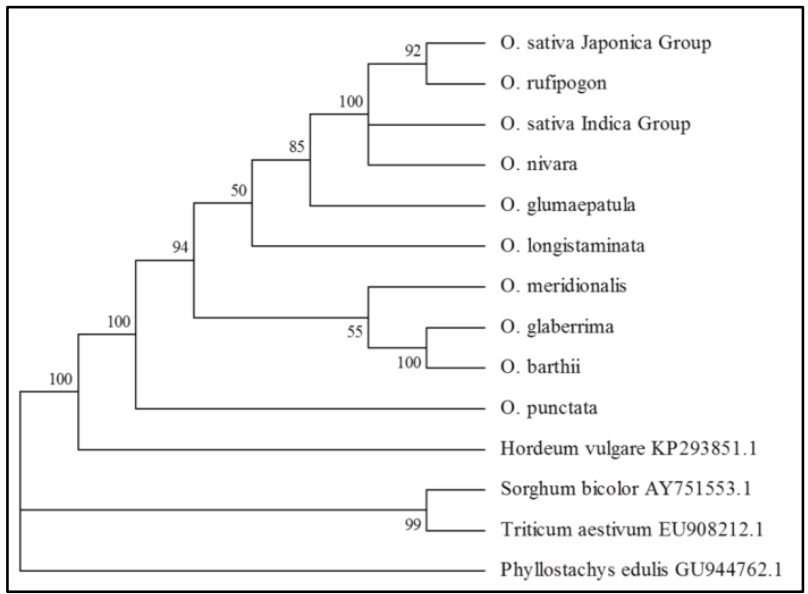

Figure 2. Phylogenetic tree of a PR10 gene retrieved from some Oryza species and the taxonomically closest monocot grasses (Sorghum bicolor, Hordeum vulgare and Zea mays) employing Maximum Likelihood method based on Kimura 2-parameter model. Bootstrap values (based on 1000 replicates) are placed as percentages at branching points. 
The clustering of all studied Oryza species in one major clade without any of the taxonomically related Gramineae species supports the taxonomic potential use of PR10 gene recorded by $(47,41)$, at least at genus level.

Analysis of the amino acid sequences for PR10 proteins retrieved from the studied Oryza genomes reflected 160 amino acid length in all species except $O$. glumipatula that exhibited a shorter amino acid chain of 158 residue (Fig. 3). However, all sequences shared GXGGXG motif (aa 44-49), characteristic for PR10 proteins (20). Results recorded in $O$. sativa are identical to results recorded by Hashimoto et al. (31) and Ozyigit et al. (40) working on the same species. However, the latter authors recorded 157-166 amino acid length in another 27 species including dicots and monocots with 3-4 amino acids position shift for the characteristic motif. Not far from these results Zandvakili et al. (27) recorded a PR10 protein of 160 amino acid length having GXGGXG motif (aa 48-53) in Zea mays. Similarly, Lebel et al. (41) documented PR10 family in vitis vinifera of $158-$ 160 amino acid length having the characteristic motif starting at the $47^{\text {th }}$ amino acid glycine residue. A relatively short PR10 protein of 154 amino acid length was recorded in Panax ginseng (42). Variation in polypeptide length and position of GXGGXG motif suggests indel mutations during the evolutionary course of PR10 gene.

Supported with instability index less than 40 (Table 2), all retrieved proteins showed in vitro stability (48). Subcellular location analysis revealed that the predicted PR10 protein is mainly a cytoplasmic protein. Besides, it was predicted to be a chloroplast protein in $O$. barthii, O. glaberrima, $O$. glumipatula, $O$. meridionalis and $O$. rufipogon (Table 2). Generally, PR10 proteins are known as interacellular PR proteins $(19,20)$. Cytoplasmic
PR10 proteins were detected in O. sativa and many other species (40). Besides cytoplasmic localization, the authors also recorded PR10 proteins in chloroplast of Gossypium barbadense, Lilium regale and Triticum aestivum. Cytoplasmic localization of PR10 was also recorded in Panax ginseng (42) and spinach (49). Interestingly, the latter research group detected PR10 proteins also in nucleus. The wide intracellular distribution of PR10 proteins may support presence of a family PR10 proteins in the same organism encoded by an equivalent group of genes (50) or presence of regulatory steps yield all candidate proteins from a smaller group of genes that require further investigation.

Compared with consensus sequence, Multalin-based alignment for amino acid sequences of the retrieved PR10 proteins (Fig. 3) reflected identical amino acid sequences in both Japonica and Indica groups of $O$. sativa as well as $O$. nivara and $O$. rufipogon. On the other hand, species-dependent variations were recorded in other species that were more pronounced in $O$. punctata. These variations had little effect on molecular masses and isoelectric points (PI) of the predicted proteins. A narrow range of molecular masses (from $16.67 \mathrm{KDa}$ in $O$. glumipatula to $16.92 \mathrm{kDa}$ in $O$. meridionalis) and PI (4.88 in all species except $O$. glaberrima and $O$. barthii showing PI of 4.9) were documented (Table 3). Generally PR10 proteins are about $17 \mathrm{KDa}$ acidic proteins $(19,20)$. 16.9 KDa PR10 protein was recorded in $O$. sativa havig PI of 4.74-4.88 (31, 40). In agreement with these results, $16.85 \mathrm{KDa}$ PR10 protein was recorded in Zea mays (27). Not far from these results, Lebel et al. (41) documented 17.1 to $18.4 \mathrm{KDa}$ PR10 family in Vitis vinifera having a theoretical pI from 4.7 to 6.3. Similarly, Bai et al. (49) documented a PR10 protein of 17.96 $\mathrm{kDa}$ and $\mathrm{pI}$ of 4.61 in spinach.

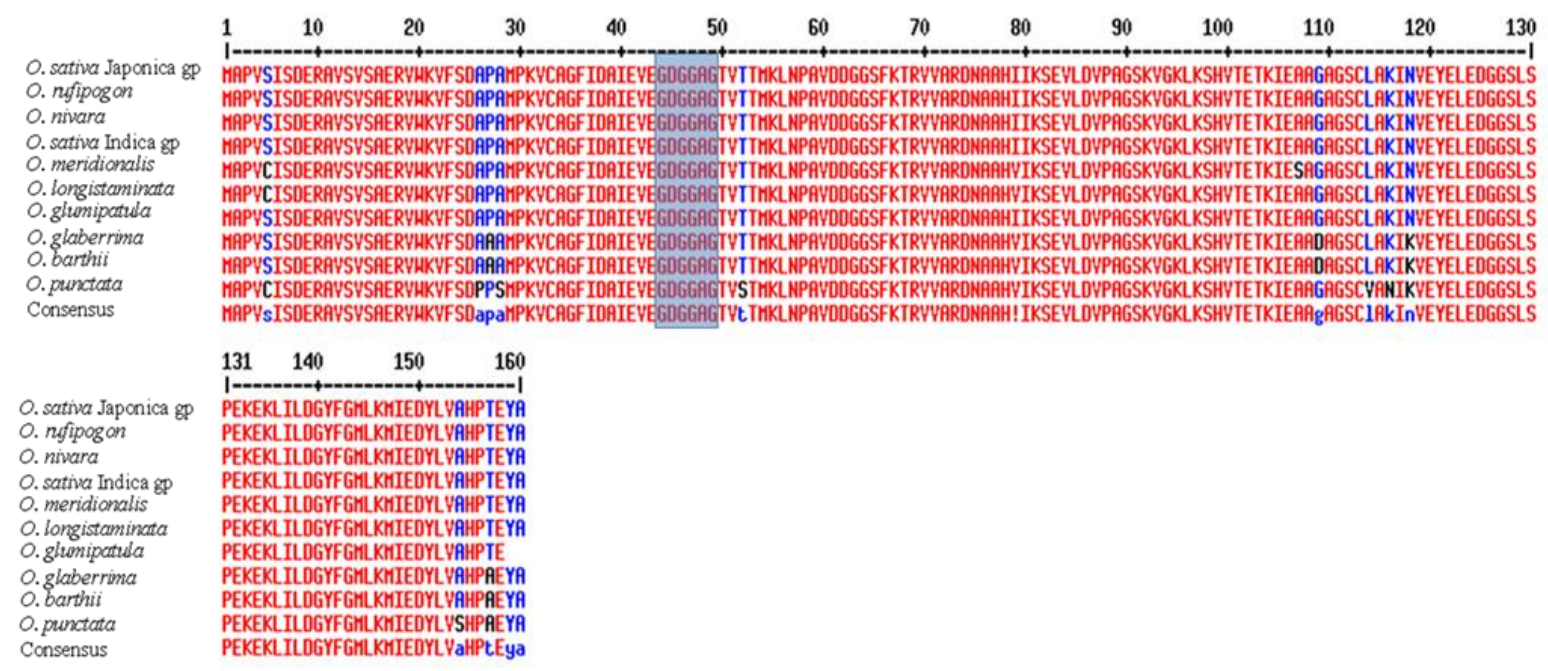

Figure 3. Multalin-based amino acid sequence alignment of a PR10 protein in some Oryza species showing GXGGXG motif. 
Table 2. Subcellular localization and physiochemical features of a PR10 protein in some Oryza species.

\begin{tabular}{|c|c|c|c|c|c|c|c|c|}
\hline Species & $\begin{array}{l}\text { Subcellular } \\
\text { location }\end{array}$ & $\begin{array}{c}\text { Molecula } \\
\text { r mass } \\
\text { (KDa) }\end{array}$ & Formula: & $\begin{array}{l}\text { No. of } \\
\text { amino } \\
\text { acids }\end{array}$ & $\begin{array}{c}\text { No. of } \\
\text { negatively } \\
\text { charged } \\
\text { residues }\end{array}$ & $\begin{array}{c}\text { No. of } \\
\text { positively } \\
\text { charged } \\
\text { residues }\end{array}$ & PI & $\begin{array}{l}\text { Instabilit } \\
\mathbf{y} \\
\text { index }\end{array}$ \\
\hline O. sativa Japonica gp & Cytoplasm & 16.90 & $\mathrm{C}_{745} \mathrm{H}_{1195} \mathrm{~N}_{195} \mathrm{O}_{237} \mathrm{~S}_{7}$ & 160 & 25 & 17 & 4.88 & 39.14 \\
\hline O. rufipogon & $\begin{array}{l}\text { Cytoplasm / } \\
\text { Chloroplast }\end{array}$ & 16.90 & $\mathrm{C}_{745} \mathrm{H}_{1195} \mathrm{~N}_{195} \mathrm{O}_{237} \mathrm{~S}_{7}$ & 160 & 25 & 17 & 4.88 & 39.14 \\
\hline o. nivara & Cytoplasm & 16.90 & $\mathrm{C}_{745} \mathrm{H}_{1195} \mathrm{~N}_{195} \mathrm{O}_{237} \mathrm{~S}_{7}$ & 160 & 25 & 17 & 4.88 & 39.14 \\
\hline O. sativa Indica gp & Cytoplasm & 16.90 & $\mathrm{C}_{745} \mathrm{H}_{1195} \mathrm{~N}_{195} \mathrm{O}_{237} \mathrm{~S}_{7}$ & 160 & 25 & 17 & 4.88 & 39.14 \\
\hline O. meridionalis & $\begin{array}{l}\text { Cytoplasm / } \\
\text { Chloroplast }\end{array}$ & 16.92 & $\mathrm{C}_{744} \mathrm{H}_{1193} \mathrm{~N}_{195} \mathrm{O}_{237} \mathrm{~S}_{8}$ & 160 & 25 & 17 & 4.88 & 37.60 \\
\hline O. longistaminata & Cytoplasm & 16.90 & $\mathrm{C}_{744} \mathrm{H}_{1193} \mathrm{~N}_{195} \mathrm{O}_{236} \mathrm{~S}_{8}$ & 160 & 25 & 17 & 4.88 & 36.39 \\
\hline O. glumipatula & $\begin{array}{l}\text { Cytoplasm / } \\
\text { Chloroplast }\end{array}$ & 16.67 & $\mathrm{C}_{733} \mathrm{H}_{1181} \mathrm{~N}_{193} \mathrm{O}_{234} \mathrm{~S}_{7}$ & 158 & 25 & 17 & 4.88 & 38.01 \\
\hline O. glaberrima & $\begin{array}{l}\text { Cytoplasm / } \\
\text { Chloroplast }\end{array}$ & 16.90 & $\mathrm{C}_{745} \mathrm{H}_{1197} \mathrm{~N}_{195} \mathrm{O}_{237} \mathrm{~S}_{7}$ & 160 & 26 & 18 & 4.90 & 32.93 \\
\hline O. barthii & $\begin{array}{l}\text { Cytoplasm / } \\
\text { Chloroplast }\end{array}$ & 16.90 & $\mathrm{C}_{745} \mathrm{H}_{1197} \mathrm{~N}_{195} \mathrm{O}_{237} \mathrm{~S}_{7}$ & 160 & 26 & 18 & 4.90 & 32.93 \\
\hline O. punctate & Cytoplasm & 16.90 & $\mathrm{C}_{743} \mathrm{H}_{1189} \mathrm{~N}_{195} \mathrm{O}_{237} \mathrm{~S}_{8}$ & 160 & 25 & 17 & 4.88 & 38.00 \\
\hline
\end{tabular}

Secondary structure and 3-D model were constructed for all retrieved PR10 proteins (Fig. 4 and 5) and 3-D dimensions were calculated (Table 3 ). The models were well supported with calculated negative values for Z-scores (51). Except dimensions of 3-D model recorded for $O$. glumipatula, variability of amino acid sequences of predicted PR10 proteins did not result in corresponding considerable variations in secondary structure (Fig. 4and Table 3) and 3-D model (Fig. 5 and Table 3). PR10 proteins exhibited a highly conserved 3-D structure of palm-like grip of seven antiparallel $\beta$ strands ( $\beta 1-\beta 7), 2$ short $\alpha$ helices (between $\beta 1$ and $\beta 2$ strands) and one long $C$ terminal $\alpha$ helix with p-loop flanked with $\beta 2$ and $\beta 3$ strands $(19,20)$. The same structure was exhibited by secondary structure and 3-D model of the predicted PR10 protein in O. glumipatula. The remaining species showed an additional short $\mathrm{C}$ terminal $\alpha$ helix. The additional helix was also recorde in $O$. sativa and Medicago truncatula (40). Interestingly, the same authors recorded only 2 helices in Prunus persica but they recorded the 3helices model in Glycine max, Solanum lycopersicum and Sorghum bicolor. The 3-helices model for PR10 proteins was also documented in Panax ginseng (42), Vitis vinifera (41) and spinach (49). Variability in number of $\alpha$ helices while conservation in number of $\beta$ strands and position of p-loop can be explained in the necessity of the latter 2 structural features in RNase activity (19).

\section{Conclusion:}

In conclusion, in silico analyses provide fast, costeffective and valuable information about the swiftly emerging genomes of wild relatives of the important strategic crops. Such information contributes adequately in breeding programs resulting in development of new cultivars of better field performance. The employed techniques reveal a high conservation at both DNA and protein levels for the candidate PR10 protein in all the examined Oryza species except $O$. glumipatula. The latter shows a relatively obvious structural variation at protein level. Such variation may be beneficial against different types of stress that requires further elucidation to exploit in rice breeding programs. 
O. sativa Japonica gp.

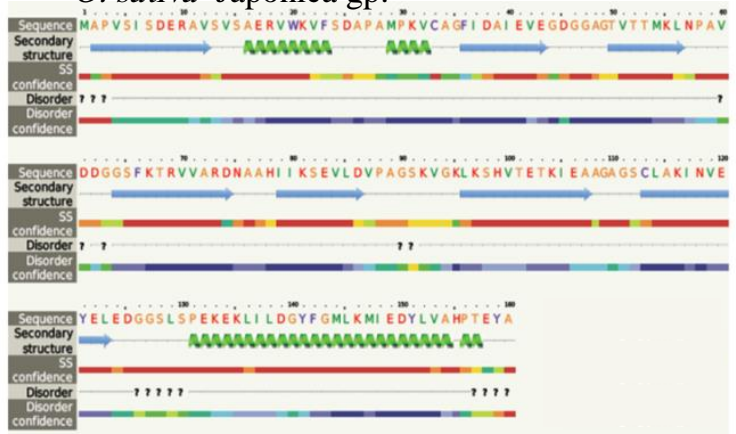

\section{O. nivara}

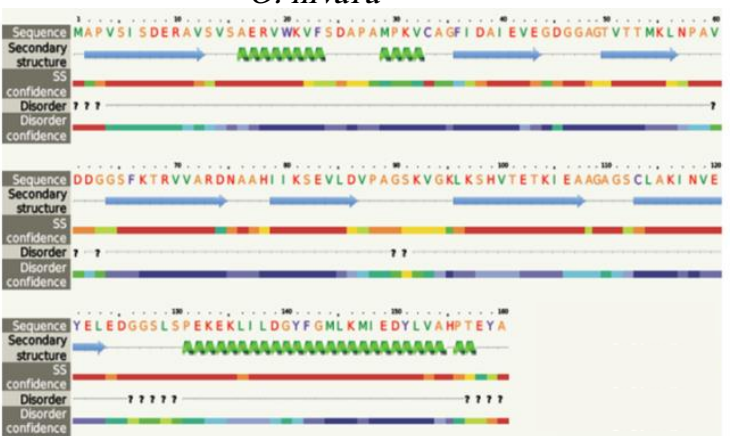

\section{O. meridionalis}

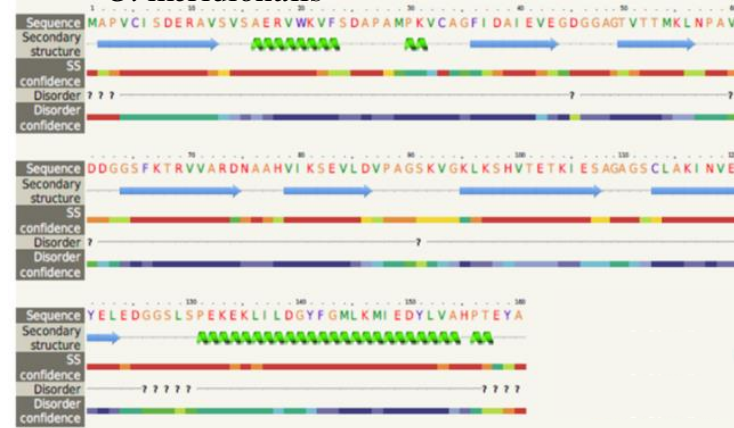

\section{O. glumaepatula}

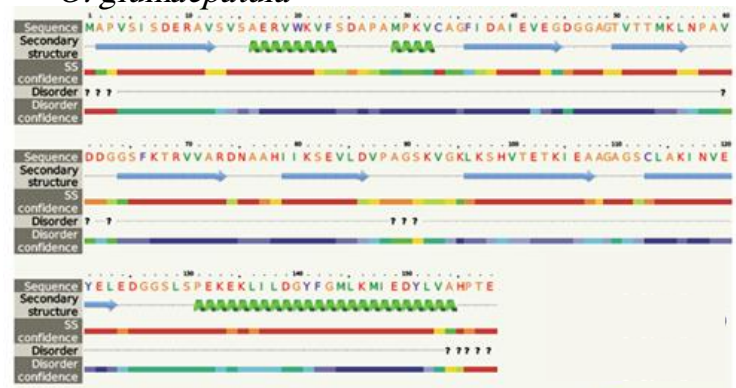

\section{O. barthii}

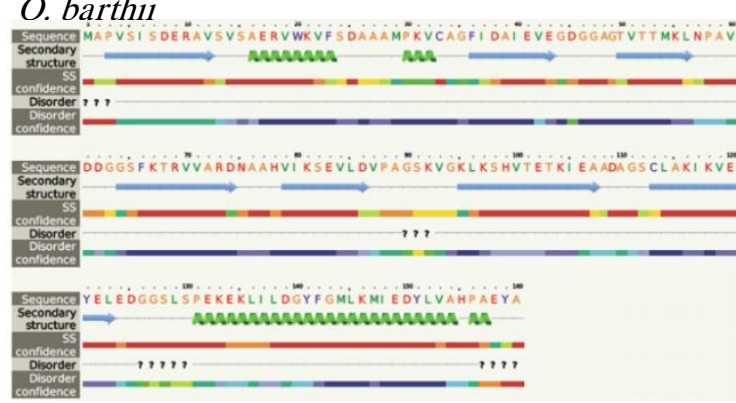

\section{O. rufipogon}

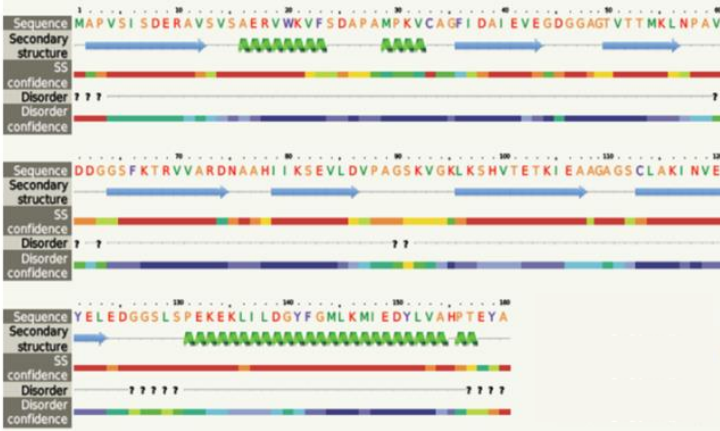

O. sativa Indica gp.

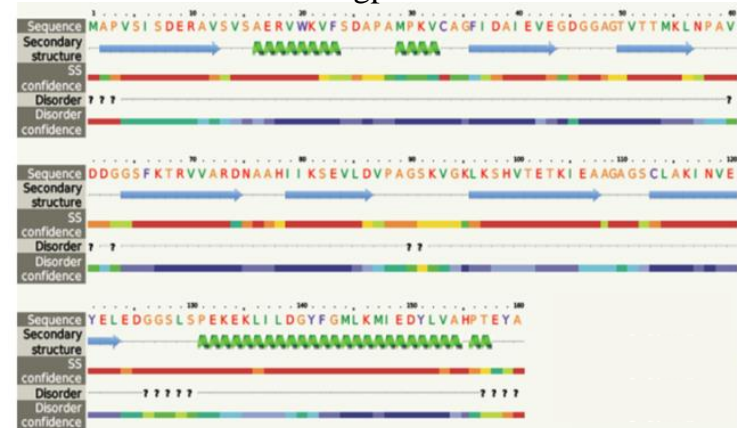

O. longistaminata

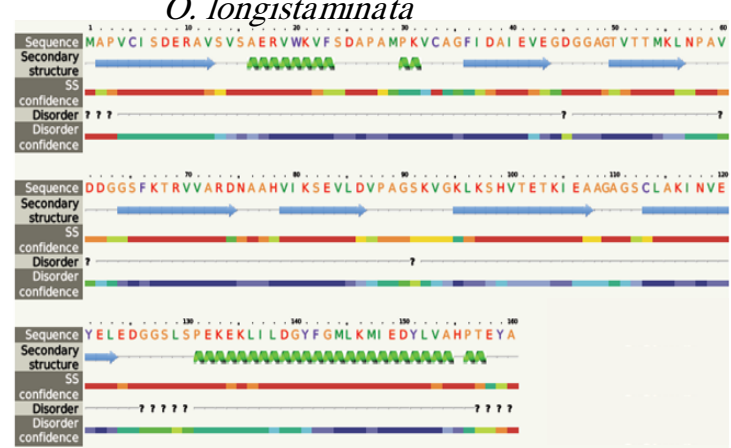

O. glaberrima

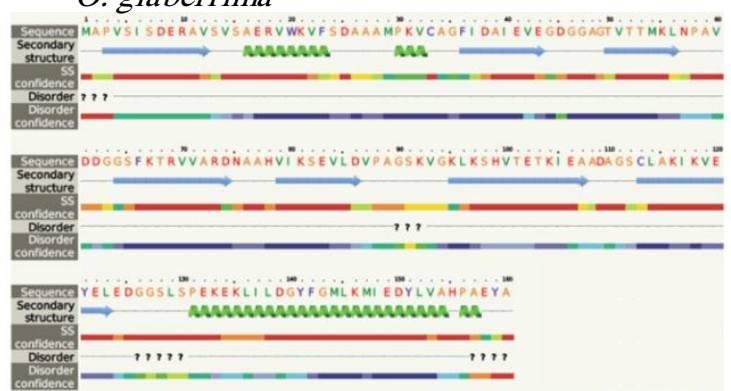

O. punctata

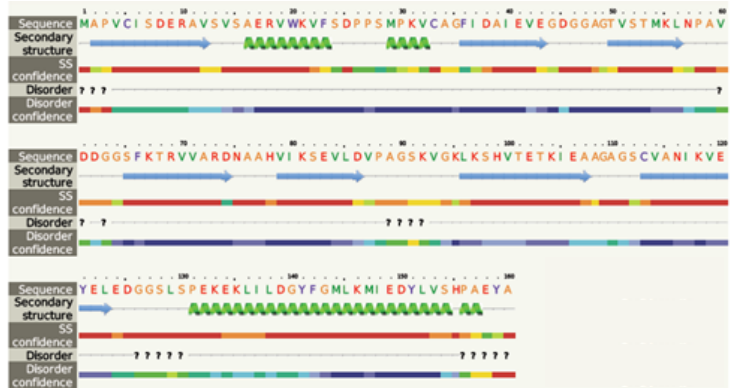

High (9)

Figure 4. Predicted secondary structure for a PR10 protein in some Oryza species. 

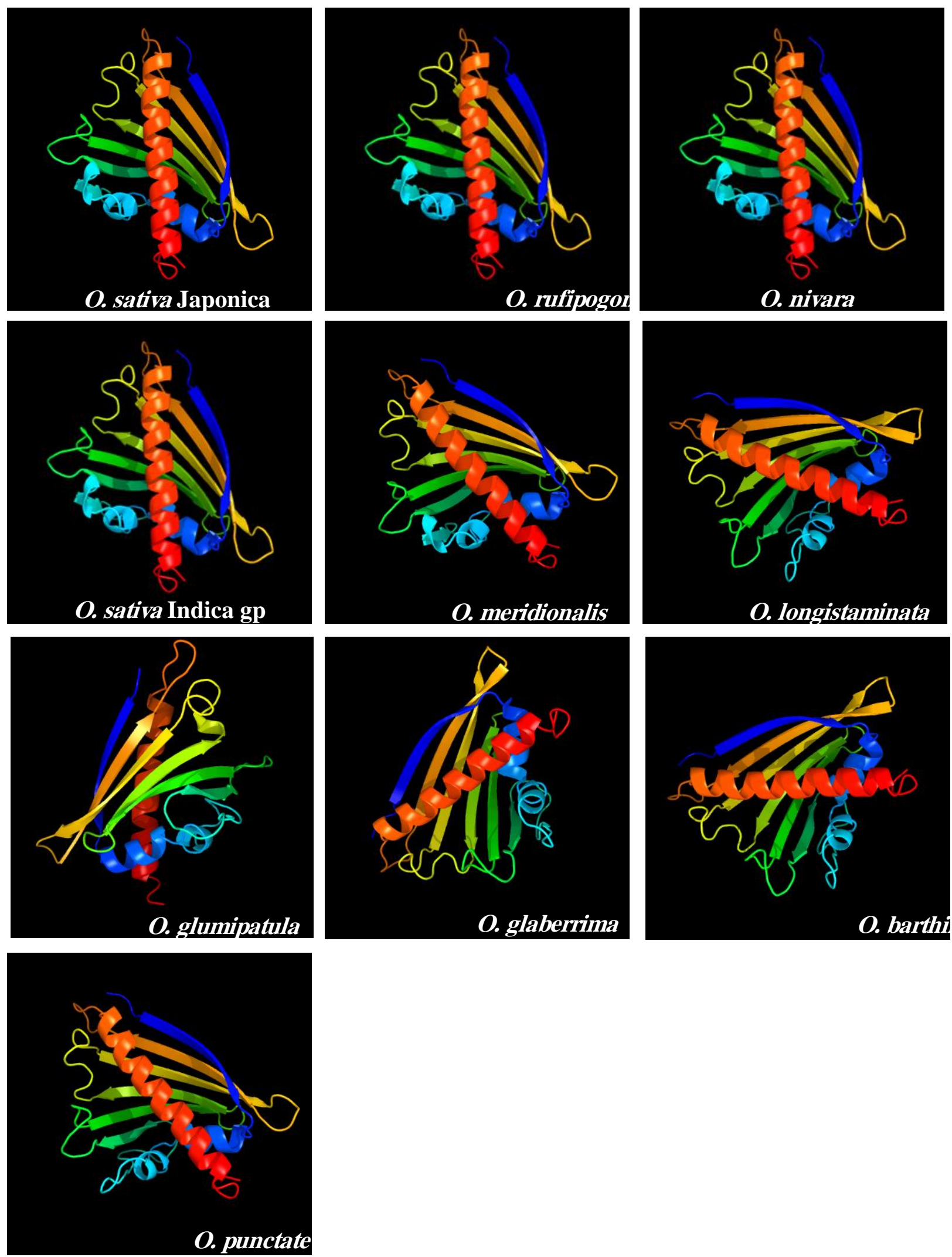

Figure 5. 3-D models predicted for a PR10 proteins in some 
Table 3. Details of secondary structure and 3-D model of a PR10 protein in some Oryza species.

\begin{tabular}{lcccccc}
\hline \multicolumn{1}{c}{ Species } & \multicolumn{2}{c}{ Secondary structure } & \multicolumn{2}{c}{ dimensions $(\AA)$} & Z-Score \\
\cline { 2 - 6 } & $\begin{array}{l}\boldsymbol{\alpha} \text { helix } \\
(\boldsymbol{\%})\end{array}$ & $\begin{array}{c}\boldsymbol{\beta} \text { strand } \\
(\boldsymbol{\%})\end{array}$ & $\mathbf{X}$ & $\mathbf{Y}$ & $\mathbf{Z}$ & \\
O. sativa Indica gp & 24 & 42 & 39.16 & 47.28 & 37.67 & -4.57 \\
O. rufipogon & 24 & 42 & 39.16 & 47.28 & 37.67 & -4.57 \\
O. nivara & 24 & 42 & 39.16 & 47.28 & 37.67 & -4.57 \\
O. sativa Japonica gp & 24 & 42 & 39.16 & 47.28 & 37.67 & -4.57 \\
O. meridionalis & 22 & 43 & 39.16 & 47.28 & 37.61 & -4.74 \\
O. longistaminata & 22 & 43 & 39.89 & 47.28 & 39.94 & -4.07 \\
O. glumipatula & 23 & 43 & 44.69 & 35.64 & 50.48 & -3.46 \\
O. glaberrima & 23 & 42 & 40.94 & 46.48 & 40.08 & -4.06 \\
O. barthii & 23 & 42 & 40.94 & 46.48 & 40.08 & -4.06 \\
O. punctate & 24 & 42 & 39.89 & 46.48 & 40.24 & -3.96 \\
\hline
\end{tabular}

\section{Conflicts of Interest: None.}

\section{References:}

1. FAOSTAT F. Available online: http://www. fao. org/faostat/en/\# data. QC (accessed on January 2018). 2017.

2. Balindong JL, Ward RM, Liu L, Rose TJ, Pallas LA, Ovenden BW,et.al. Rice grain protein composition influences instrumental measures of rice cooking and eating quality. J Cereal Sci. 2018;79:35-42.

3. Szareski VJ, Carvalho IR, da Rosa TC, Dellagostin SM, de Pelegrin AJ, Barbosa MH, et.al. Oryza Wild Species: An alternative for rice breeding under abiotic stress conditions. Am J Plant Sci. 2018; 9(06):1093.

4. Kilasi NL, Singh J, Vallejos CE, Ye C, Jagadish SK, Kusolwa $\mathrm{P}$,et.al. Heat stress tolerance in rice (Oryza sativa L.): Identification of quantitative trait loci and candidate genes for seedling growth under heat stress. Front Plant Sci. 2018 Nov 1;9:1578..

5. Zhu Q, Zheng X, Luo J, Gaut BS, Ge S. Multilocus analysis of nucleotide variation of Oryza sativa and its wild relatives: severe bottleneck during domestication of rice. Mol Biol Evol. 2007;24(3):875-88.

6. Palmgren MG, Edenbrandt AK, Vedel SE, Andersen MM, Landes X, Østerberg JT, et.al. Are we ready for back-to-nature crop breeding?. Trends Plant Sci. 2015;20(3):155-64.

7. Atwell BJ, Wang H, Scafaro AP. Could abiotic stress tolerance in wild relatives of rice be used to improve Oryza sativa?. Plant Sci. 2014;215:48-58.

8. Li JY, Liu J, Dong D, Jia X, McCouch SR, Kochian LV. Natural variation underlies alterations in Nramp aluminum transporter (NRAT1) expression and function that play a key role in rice aluminum tolerance. Proc Natl Acad Sci U S A. 2014;111(17):6503-8.

9. Yan J, Wang P, Wang P, Yang M, Lian X, Tang Z, et.al. A loss-of-function allele of OsHMA3 associated with high cadmium accumulation in shoots and grain of Japonica rice cultivars. Plant Cell Environ. 2016;39(9):1941-54.

10. Egan PA, Muola A, Stenberg JA. Capturing genetic variation in crop wild relatives: An evolutionary approach. Evol Appl. 2018;11(8):1293-304.

11. International RG. The map-based sequence of the rice genome. Nature. 2005;436(7052):793.

12. Murray D, Doran P, MacMathuna P, Moss AC. In silico gene expression analysis-an overview. Mol cancer. 2007;6(1):50.

13. Yaqoob U, Kaul T, Pandey S, Nawchoo IA. In-silico characterization, structural modelling, docking studies and phylogenetic analysis of 5enolpyruvylshikimate-3-phosphate synthase gene of Oryza sativa L. Med Aromat Plants (Los Angel). 2016;5(274):2167-0412.

14. Bhati J, Chaduvula KP, Rai A, Gaikwad K, Soma M. S. In-Silico Prediction and Functional Analysis of Salt Stress Responsive Genes in Rice (Oryza sativa). J Rice Res. 2016;4(164):2.

15. Kaur A, Pati PK, Pati AM, Nagpal AK. In-silico analysis of cis-acting regulatory elements of pathogenesis-related proteins of Arabidopsis thaliana and Oryza sativa. PloS one. 2017;12(9):e0184523.

16. Rawal HC, Mithra SA, Arora K, Kumar V, Goel N, Mishra DC, et.al. Genome-wide analysis in wild and cultivated Oryza species reveals abundance of NBS genes in progenitors of cultivated rice. Plant Mol Biol Rep. 2018;36(3):373-86.

17. Fouad AS, Hafez RM, In silico characterization of CDKB1 and its coding gene in some Oryza species. Biosci Res. 2019; 16(2): 1679-1690.

18. Ali S, Ganai BA, Kamili AN, Bhat AA, Mir ZA, Bhat JA, et.al. Pathogenesis-related proteins and peptides as promising tools for engineering plants with multiple stress tolerance. Microbiol Res. 2018;212:29-37.

19. Liu JJ , Ekramoddoullah AK. The family 10 of plant pathogenesis-related proteins: their structure, regulation, and function in response to biotic and 
abiotic stresses. Physiol Mol Plant Pathol. 2006;68(13):3-13.

20. Fernandes H, Michalska K, Sikorski M, Jaskolski M. Structural and functional aspects of PR-10 proteins. FEBS J. 2013;280(5):1169-99.

21. Mogensen JE, Ipsen $\mathrm{H}$, Holm J , Otzen DE. Elimination of a misfolded folding intermediate by a single point mutation. Biochemistry. 2004;43(12):3357-67.

22. Somssich IE, Schmelzer E, Bollmann J , Hahlbrock K. Rapid activation by fungal elicitor of genes encoding "pathogenesis-related" proteins in cultured parsley cells. Proc Natl Acad Sci U S A. 1986;83(8):2427-30.

23. Somssich IE, Schmelzer E, Kawalleck P, Hahlbrock $\mathrm{K}$. Gene structure and in situ transcript localization of pathogenesis-related protein 1 in parsley. Mol Gen Genet. 1988;213(1):93-8.

24. Wieczorek P, Wrzesińska B, Frąckowiak P, Przybylska A , Obrępalska-Stęplowska A. Contribution of tomato torrado virus Vp26 coat protein subunit to systemic necrosis induction and virus infectivity in Solanum lycopersicum. Virol J. 2019;16(1):9.

25. Besbes F, Habegger R, Schwab W. Induction of PR10 genes and metabolites in strawberry plants in response to Verticillium dahliae infection. BMC Plant Biol. 2019;19(1):128.

26. Castro A, Vidal S, Ponce de León I. Moss pathogenesis-related-10 protein enhances resistance to Pythium irregulare in Physcomitrella patens and Arabidopsis thaliana. Front Plant Sci. 2016;7:580.

27. Zandvakili N, Zamani M, Motallebi M, Jahromi ZM. Cloning, Overexpression and in vitro Antifungal Activity of Zea mays PR10 Protein. Iran J Biotechnol. 2017;15(1):42.

28. El-Banna A, Hajirezaei MR, Wissing J, Ali Z, Vaas L, Heine-Dobbernack E, et al. Over-expression of PR-10a leads to increased salt and osmotic tolerance in potato cell cultures. J Biotechnol. 2010;150(3):277-87.

29. Karppinen K, Derzsó E, Jaakola L , Hohtola A. Molecular cloning and expression analysis of hyp-1 type PR-10 family genes in Hypericum perforatum. Front Plant Sci. 2016;7:526.

30. Agarwal P , Agarwal PK. Jatropha curcas pathogenesis related-10a Protein: a jack of many trades via cytokinin signaling. Clon Transgen. 2016;5:152.

31. Hashimoto M, Kisseleva L, Sawa S, Furukawa T, Komatsu S , Koshiba T. A novel rice PR10 protein, RSOsPR10, specifically induced in roots by biotic and abiotic stresses, possibly via the jasmonic acid signaling pathway. Plant Cell Physiol. 2004;45(5):550-9.

32. Tamura K, Stecher G, Peterson D, Filipski A, Kumar S. MEGA6: molecular evolutionary genetics analysis version 6.0. Mol Biol Evol. 2013;30(12):2725-9.

33. Kimura M. A simple method for estimating evolutionary rates of base substitutions through comparative studies of nucleotide sequences. J Mol Evol. 1980;16(2):111-20.

34. Felsenstein J. Confidence limits on phylogenies: an approach using the bootstrap. Evolution. 1985;39(4):783-91.

35. Corpet F. Multiple sequence alignment with hierarchical clustering. Nucleic Acids Res. 1988;16(22):10881-90.

36. Gasteiger E, Hoogland C, Gattiker A, Wilkins MR, Appel RD, Bairoch A. Protein identification and analysis tools on the ExPASy server. InThe proteomics protocols handbook 2005 (pp. 571-607). Humana press.

37. Yu CS, Cheng CW, Su WC, Chang KC, Huang SW, Hwang JK et.al. CELLO2GO: a web server for protein subCELlular LOcalization prediction with functional gene ontology annotation. PloS one. 2014;9(6):e99368.

38. Kelley LA, Mezulis S, Yates CM, Wass MN , Sternberg MJ. The Phyre2 web portal for protein modeling, prediction and analysis. Nat Protoc. 2015;10(6):845.

39. Wiederstein M, Sippl MJ. ProSA-web: interactive web service for the recognition of errors in threedimensional structures of proteins. Nucleic Acids Res. 2007;35(suppl_2):W407-10.

40. Ozyigit II, Vatansever R, Filiz E. Comparative analyses of pathogenesis-related protein-10 (PR10) in plants. Indian J Biotechnol. 2017; 16: 456-464.

41. Lebel S, Schellenbaum P, Walter B, Maillot P. Characterisation of the Vitis vinifera PR10 multigene family. BMC Plant Biol. 2010;10(1):184.

42. Han JH, Lee JH, Lee OR. Leaf-specific pathogenesis-related 10 homolog, PgPR-10.3, shows in silico binding affinity with several biologically important molecules. J Ginseng Res. 2015;39(4):40613.

43. Duan S, Lu B, Li Z, Tong J, Kong J, Yao W, et.al. Phylogenetic analysis of AA-genome Oryza species (Poaceae) based on chloroplast, mitochondrial, and nuclear DNA sequences. Biochem Genet. 2007;45(12):113-29.

44. Wambugu PW, Brozynska M, Furtado A, Waters DL , Henry RJ. Relationships of wild and domesticated rices (Oryza AA genome species) based upon whole chloroplast genome sequences. Sci Rep. 2015;5:13957.

45. Brozynska M, Copetti D, Furtado A, Wing RA, Crayn D, Fox G, et.al. Sequencing of Australian wild rice genomes reveals ancestral relationships with domesticated rice. Plant Biotechnol J. 2017;15(6):765-74.

46. Liao Y, Zhang X, Li B, Liu T, Chen J, Bai Z, et.al. Comparison of Oryza sativa and Oryza brachyantha genomes reveals selection-driven gene escape from the centromeric regions. Plant Cell. 2018;30(8):172944.

47. Schenk MF, Cordewener JH, America AH, van't Westende WP, Smulders MJ and Gilissen LJ. Characterization of PR-10 genes from eight Betula species and detection of Bet $\mathrm{v} 1$ isoforms in birch pollen. BMC Plant Biol. 2009;9(1):24.

48. Guruprasad K, Reddy BB , Pandit MW. Correlation between stability of a protein and its dipeptide composition: a novel approach for predicting in vivo stability of a protein from its primary sequence. 
Protein Eng Des Sel. 1990;4(2):155-61.

49. Bai X, Long J, He X, Li S, Xu H. Molecular cloning and characterization of pathogenesis-related protein family 10 gene from spinach (SoPR10). Biosci Biotechnol Biochem. 2014;78(5):780-6.

50. Gao ZS, Van de Weg WE, Schaart JG, Schouten HJ, Tran DH, Kodde LP, Van der Meer IM, et.al.. Genomic cloning and linkage mapping of the Mal d 1
(PR-10) gene family in apple (Malus domestica). Theor Appl Genet. 2005;111(1):171-83.

51. Moraes Filho RM, Menezes AF, Martins LS. In silico modeling and characterization of phytoparasitic nematodes translationally-controlled tumor proteins. Genet Mol Res. 2017;16(3).

\section{النمذجة الجزيئية و توصيف أحد البروتينات المرتبطة بالآفات من المجموعة العاثرة و الجينات الخاصة به

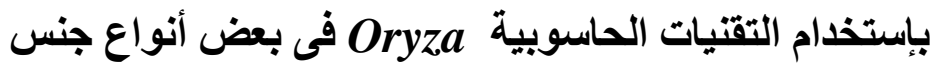

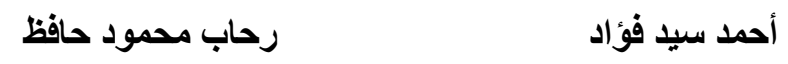

قسم النبات و الميكروبيولوجى، كلية العلوم، جامعة القاهرة-القاهرة-جمهورية مصر العربية (ص ب 12613)

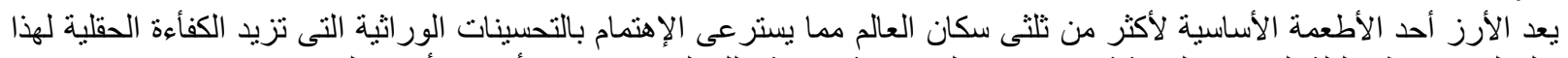

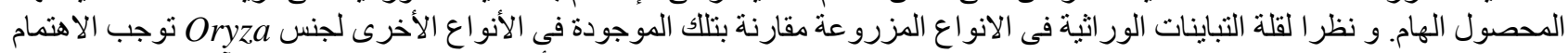

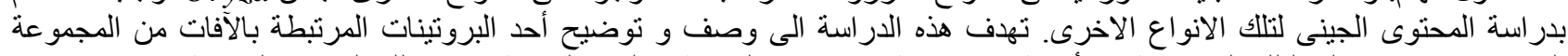

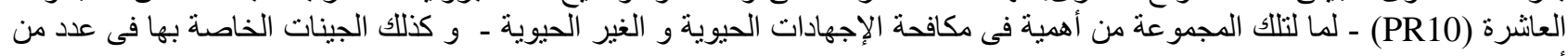

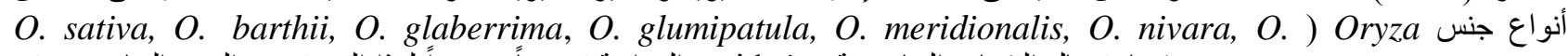

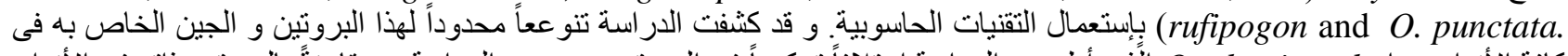

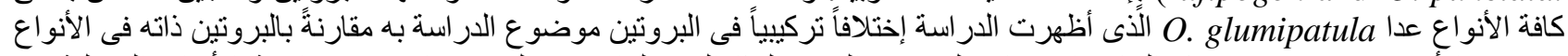
الإنهرى. Oryza

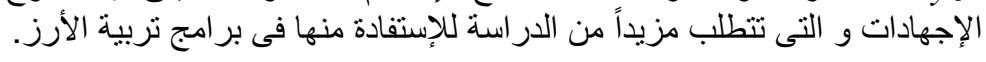

$$
\text { الكلمات المفتاحية: الجينومات ،أرز، الأقارب البرية. }
$$

